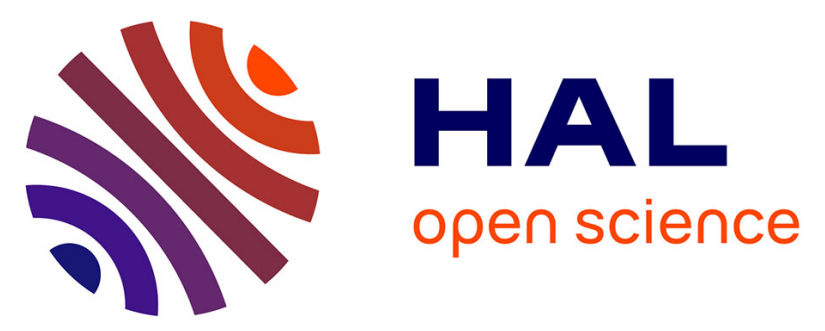

\title{
Efficient synthesis of novel dialkyl-3-cyanopropylphosphate derivatives and evaluation of their anticholinesterase activity
}

Iyadh Aouani, Badreddine Sellami, Karima Lahbib, Jean-François Cavalier, Soufiane Touil

\section{To cite this version:}

Iyadh Aouani, Badreddine Sellami, Karima Lahbib, Jean-François Cavalier, Soufiane Touil. Efficient synthesis of novel dialkyl-3-cyanopropylphosphate derivatives and evaluation of their anticholinesterase activity. Bioorganic Chemistry, 2017, 72, pp.301 - 307. 10.1016/j.bioorg.2017.05.008 . hal-03470621

\section{HAL Id: hal-03470621 \\ https://hal.science/hal-03470621}

Submitted on 8 Dec 2021

HAL is a multi-disciplinary open access archive for the deposit and dissemination of scientific research documents, whether they are published or not. The documents may come from teaching and research institutions in France or abroad, or from public or private research centers.
L'archive ouverte pluridisciplinaire HAL, est destinée au dépôt et à la diffusion de documents scientifiques de niveau recherche, publiés ou non, émanant des établissements d'enseignement et de recherche français ou étrangers, des laboratoires publics ou privés. 


\section{Accepted Manuscript}

Efficient synthesis of novel dialkyl-3-cyanopropylphosphate derivatives and evaluation of their anticholinesterase activity

Iyadh Aouani, Badreddine Sellami, Karima Lahbib, Jean-François Cavalier, Soufiane Touil

PII: S0045-2068(17)30072-X

DOI: http://dx.doi.org/10.1016/j.bioorg.2017.05.008

Reference: YBIOO 2070

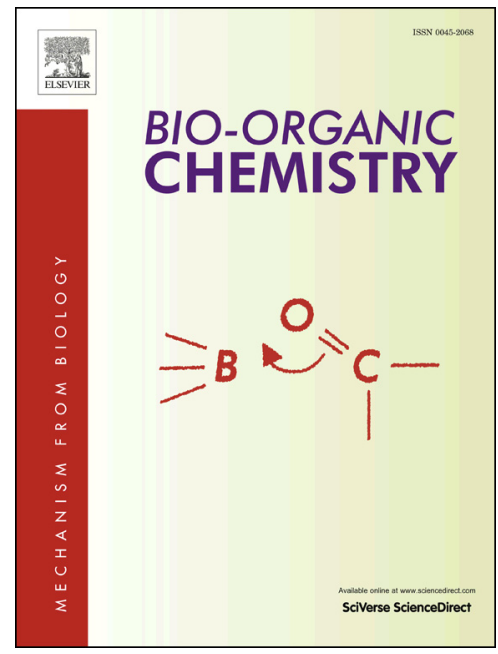

To appear in:

Bioorganic Chemistry

Received Date:

5 February 2017

Revised Date: 30 April 2017

Accepted Date: 4 May 2017

Please cite this article as: I. Aouani, B. Sellami, K. Lahbib, J-F. Cavalier, S. Touil, Efficient synthesis of novel dialkyl-3-cyanopropylphosphate derivatives and evaluation of their anticholinesterase activity, Bioorganic Chemistry (2017), doi: http://dx.doi.org/10.1016/j.bioorg.2017.05.008

This is a PDF file of an unedited manuscript that has been accepted for publication. As a service to our customers we are providing this early version of the manuscript. The manuscript will undergo copyediting, typesetting, and review of the resulting proof before it is published in its final form. Please note that during the production process errors may be discovered which could affect the content, and all legal disclaimers that apply to the journal pertain. 


\title{
Efficient synthesis of novel dialkyl-3-cyanopropylphosphate derivatives and evaluation of their anticholinesterase activity
}

\author{
Iyadh Aouani a, Badreddine Sellami b, Karima Lahbib a , Jean-François Cavalier c, \\ Soufiane Touil ${ }^{\mathrm{a}, *}$
}

${ }^{a}$ Laboratory of Heteroatom Organic Chemistry, University of Carthage, Faculty of Sciences of Bizerte, 7021-Jarzouna, Tunisia.

${ }^{b}$ Laboratory of Environment Biomonitoring, Coastal Ecology Unit, University of Carthage, Faculty of Sciences of Bizerte, 7021-Jarzouna, Tunisia.

${ }^{c}$ Aix-Marseille University, CNRS, EIPL, Marseille, France.

\begin{abstract}
:
Based on the broad spectrum of biological activities associated with organophosphates, a novel type of this class of compounds was synthesized, bearing a nitrile group, from the sodium alkoxide-catalyzed reaction of dialkylphosphites with $\gamma$-ketonitriles at $80{ }^{\circ} \mathrm{C}$ under solvent-free conditions. A reaction mechanism involving a phospha-Brook type rearrangement is proposed. Eight title compounds were investigated for their in vitro inhibitory potency and selectivity against acetylcholinesterase (AChE) and butyrylcholinesterase (BChE) using Ellman's spectrophotometric method. The synthesized derivatives exhibited mostly a moderate activity against both cholinesterases. The $\mathrm{IC}_{50}$ values for $\mathrm{BChE}$ were in a smaller concentration range (5.96-23.35 $\mu \mathrm{M})$ compared to those for AChE inhibition (9.61-53.74 $\mu \mathrm{M})$. The diethyl-3-cyano1-p-tolylpropylphosphate which displayed the higher dual inhibitory potency towards both cholinesterases could be considered as a potential candidate for developing new drugs to treat Alzheimer's disease.
\end{abstract}

Keywords: Organophosphates; $\gamma$-Ketonitriles; Dialkyl-3-cyanopropylphosphates; PhosphaBrook rearrangement; Cholinesterase inhibitors.

\footnotetext{
* Corresponding author. E-mail address: soufiane.touil@ fsb.rnu.tn (S. Touil).
} 


\section{Introduction}

Alzheimer's disease, the most common form of neurodegenerative senile dementia, is associated with the selective loss of cholinergic neurons and a reduced level of the acetylcholine (ACh) neurotransmitter. The cholinergic hypothesis postulates that Alzheimer's disease (AD) is caused by a decrease in ACh levels in the brain, leading to gradual neurodegeneration [1]. In normal brain signaling, ACh is related to the preservation and access to memory as well as function [1]. Acetylcholinesterase (AChE), a drug target for Alzheimer's disease, is an enzyme that belongs to the very large serine hydrolase class of enzymes [2]. AChE catalyzes the hydrolysis of ACh to choline and acetic acid which allows the control of the ACh level and to regulate its action as a cholinergic neurotransmitter interacting with postsynaptic cell receptors. This enzyme is widely distributed throughout the body and is the main cholinesterase in the human brain [3,4]. Additionally, Butyrylcholinesterase (BChE) plays a secondary role in the regulation of the ACh level and compensates for the lack of $\mathrm{AChE}$, allowing the cholinergic neurotransmission to continue [5-7].

Inhibitors of $\mathrm{ChE}$ have been used in the treatment of various diseases such as Alzheimer's, myasthenia gravis and some other dementias [8], parasitic infections [9], glaucoma and obstipation [10].

Organophosphates are well-known anticholinesterase agents [11,12]. They cause irreversible inhibition of both $\mathrm{AChE}$ and $\mathrm{BChE}$ by phosphorylation of the active site catalytic serine hydroxyl group [13], thus inhibiting its physiologic action of hydrolyzing the ACh neurotransmitter at the central and peripheral synapses $[8,14]$. This results in ACh accumulation and in thus an over-stimulation of cholinergic receptors [15]. For instance, salicylanilide diethyl phosphates were found to be excellent inhibitors of both $\mathrm{AChE}$ and $\mathrm{BChE}$ with $\mathrm{IC}_{50}$ values in the micromolar range, and in some cases they exhibited even better inhibitory activity than the current AD medications Rivastigmine and Galantamine [11,16].

In the present study, we report a simple synthesis of the novel dialkyl-3cyanopropylphosphates starting from dialkyl phosphites and $\gamma$-ketonitriles. A preliminary evaluation of the inhibitory activities of $\mathrm{AChE}$ and $\mathrm{BChE}$ is also reported for eight dialkyl-3cyanopropylphosphate derivatives. It should be noted that the presence of the nitrile unit in these molecules might regulate important biological functions and could improve the biological 
activity of such compounds by accentuating the binding to receptor targets, in a similar way to that reported for other pharmaceuticals [17].

\section{Results and discussion}

\subsection{Chemistry}

We first aimed at optimizing the reaction conditions for the formation of the dialkyl-3cyanopropylphosphate target compounds, by using $\gamma$-ketonitrile 1a and diethyl phosphite as model substrates. The reaction was studied with various basic catalysts under different conditions. The results of these comparative experiments are summarized in Table 1. Inspired by our previous work regarding the synthesis of $\gamma$-cyano- $\alpha$-hydroxyphosphonates via the reaction of $\gamma$-ketonitriles with dialkyl phosphites on magnesia support at room temperature and in solventfree conditions [18], we thought that conducting the same reaction at a higher temperature may lead, after a phospha-Brook type rearrangement [19] promoted by heat, to the corresponding dialkyl-3-cyanopropylphosphate 3a. Contrary to our expectations, the reaction did not yield the desired product but gave the corresponding $\alpha$-hydroxyphosphonate 3'a with less than $30 \%$ yields (Table 1, entries 1 and 2). The use of $\mathrm{K}_{2} \mathrm{CO}_{3}$ and amines as basic catalysts was also tested, but this left the starting materials intact even after prolonged heating (Table 1, entries 3-7). An improvement in the yield of product 3a was however observed when employing sodium ethoxide as catalyst under solvent-free conditions (Table 1, entry 9). Finally, under the same reaction conditions and by increasing the amount of diethyl phosphite up to 5 molar equivalents, it was gratifying to obtain the desired product $3 \mathbf{a}$ with $85 \%$ yield (Table 1, entry 10 ). 
Table 1. Optimization of the reaction conditions.

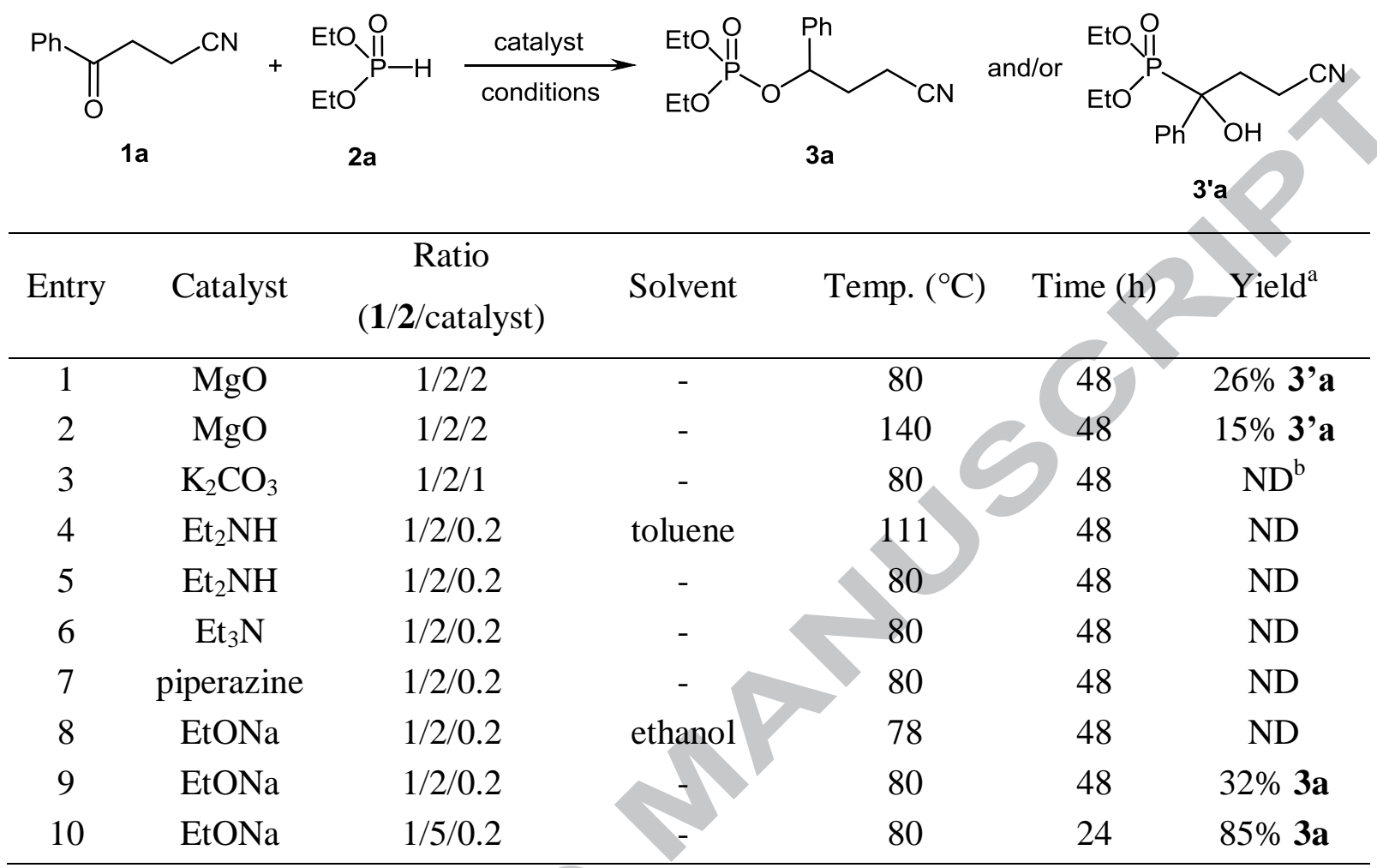

${ }^{\mathrm{a}}$ Isolated yield.

${ }^{\mathrm{b}}$ No products detected.

Once the optimized reaction conditions were obtained, the scope of this methodology was studied. A variety of structurally diverse $\gamma$-ketonitriles and dialkyl phosphites were investigated and a series of dialkyl-3-cyanopropylphosphates of type $\mathbf{3}$ were obtained in good yields (Table 2). Compounds $\mathbf{3 g}$ and $\mathbf{3 h}$, presenting two stereocenters, were obtained as a mixture of two unseparable diastereoisomers in an approximate 3:2 ratio, as evidenced by their NMR spectral data. The relative proportions of these diastereoisomers were estimated from the ${ }^{31} \mathrm{P} N M R$ spectra where a singlet for each one was found (see experimental section).

A mechanistic rationalization of this reaction is depicted in Scheme 1. In this proposed mechanism, the role of sodium alkoxide is to promote the deprotonation of dialkyl $\mathrm{H}$ phosphonate 2 giving rise to the more nucleophilic dialkylphosphite anion which can react with the carbonyl of the $\gamma$-ketonitrile $\mathbf{1}$ to supply an $\alpha$-hydroxyphosphonate $\mathbf{I}_{\mathbf{2}}$ as intermediate, in equilibrium with the alkoxide form $\mathbf{I}_{\mathbf{1}}$. When heating, the latter undergoes a phospha-Brook type 
rearrangement [19] that consists in an intramolecular 1,2-migration of the phosphoryl group from carbon to oxygen. This includes the formation of a three-membered cyclic species from intermediate $\mathbf{I}_{\mathbf{1}}$. Subsequent ring opening and irreversible fast protonation of the carbanion by the dialkyl phosphite, lead to the final dialkyl-3-cyanopropylphosphate 3.

Table 2. Substrate scope studies.

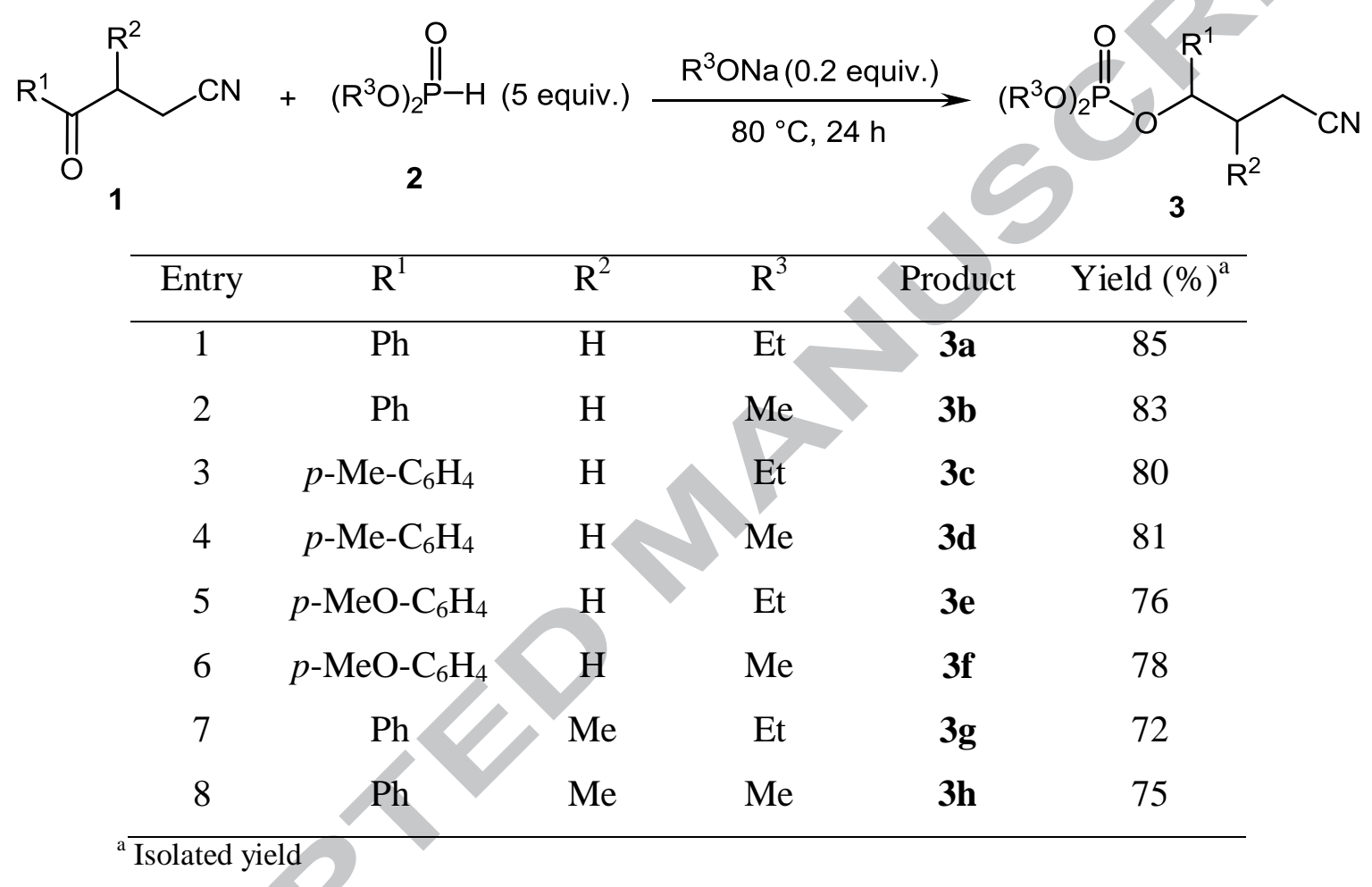




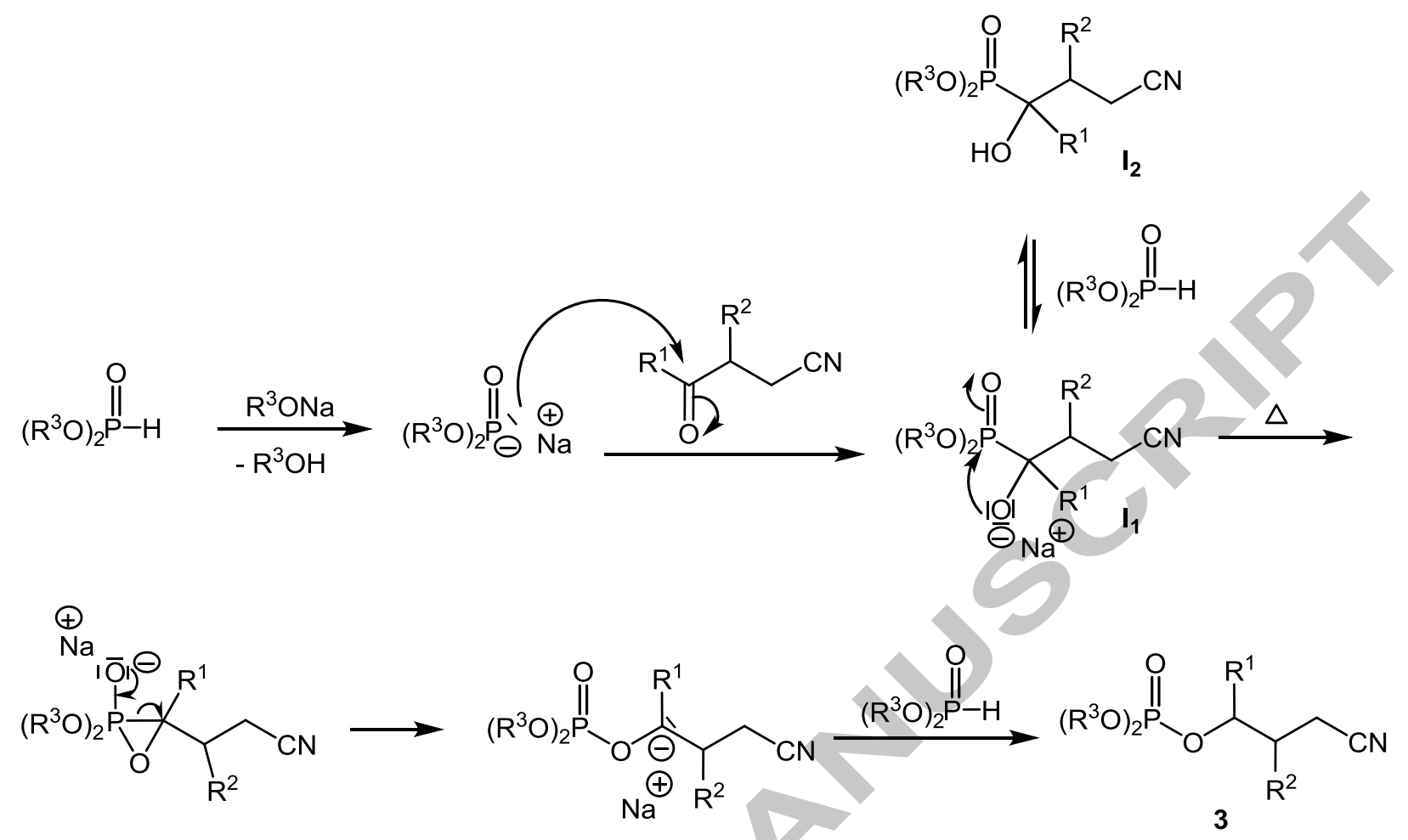

Scheme 1. Proposed mechanism for the formation of dialkyl-3-cyanopropylphosphates 3 .

\subsection{Anticholinesterase activity}

The inhibitory potency of the eight newly synthesized dialkyl-3-cyanopropylphosphates against $\mathrm{AChE}$ and BChE were evaluated in vitro using modified Ellman's method [20]. The efficiency of these inhibitors is expressed as $\mathrm{IC}_{50}$, representing the concentration of an inhibitor leading to $50 \%$ inhibition of the enzyme. The obtained results were compared with Rivastigmine, an acylating pseudo-irreversible carbamate inhibitor that is able to inhibit both AChE and BChE.

With respect to the inhibition of cholinesterases, all tested dialkyl-3cyanopropylphosphates exhibited a significant inhibitory power towards AChE and BChE, with $\mathrm{IC}_{50}$ values ranging from 5.96 to $53.74 \mu \mathrm{M}$ (Table 3 ). In addition, and as awaited from previous studies with phosphate inhibitors [11,13b], compounds 3a-h showed greater inhibition of both enzymes than Rivastigmine. This result is probably related to the chemical structure of the 3a-h molecules which contains a good leaving group $\left(-\mathrm{O}-\mathrm{CH}\left(\mathrm{R}^{1}\right)-\mathrm{CH}\left(\mathrm{R}^{2}\right)-\mathrm{CH}_{2}-\mathrm{CN}\right)$ enabling them to perform the phosphorylation of the nucleophilic serine hydroxyl group in the active site of the ChE enzymes. In addition, the cyano group present in these molecules could contribute to this 
activity by its electron-withdrawing inductive effect which increases the leaving group ability of the 3-cyanopropyloxy moiety.

Moreover, in agreement with previous studies showing that organophosphorus molecules behave more selectively towards $\mathrm{BChE}[11,21,22]$, we also demonstrated that our dialkyl-3cyanopropylphosphates 3a-h inhibited BChE more effectively than AChE, by 1.43- to 2.59-fold for $\mathbf{3 h}$ and $\mathbf{3 e}$, respectively. Only compound $\mathbf{3 d}$ exhibited comparable $\mathrm{IC}_{50} \mathrm{~S}$ for both enzymes.

Among the eight tested compounds, the most potent inhibitor of $\mathrm{AChE}$ was found to be the diethyl-3-cyano-1-p-tolylpropylphosphate (3c) with an $\mathrm{IC}_{50}$ value of $9.61 \mu \mathrm{M}$, which is also the best inhibitor of $\mathrm{BChE}\left(\mathrm{IC}_{50}=5.96 \mu \mathrm{M}\right)$. In contrast, the diethyl-3-cyano-1-(4methoxyphenyl)propylphosphate (3e) was the weakest inhibitor of $\mathrm{AChE}\left(\mathrm{IC}_{50}=53.74 \mu \mathrm{M}\right)$; while the dimethyl-3-cyano-1-(4-methoxyphenyl)propylphosphate $\mathbf{3 f}\left(\mathrm{IC}_{50}=23.35 \mu \mathrm{M}\right)$ was assayed as the least effective inhibitor of $\mathrm{BChE}$.

Despite the low number of compounds tested, some trends in terms of structure-activity relationships have however emerged based on the substitution and activity of our dialkyl-3cyanopropylphosphates $\mathbf{3 a}-\mathbf{h}$. First, whatever the substitution at $\mathrm{R}^{2}$ and the $\mathrm{R}^{3}$ chain at the phosphorus atom, compounds $\mathbf{3 a - b}, \mathbf{g}-\mathbf{h}$ bearing a phenyl group in $\mathrm{R}^{1}$ position displayed the same medium inhibitory activity towards either $\mathrm{AChE}$ (mean $\mathrm{IC}_{50}=32.56 \pm 2.37 \mu \mathrm{M}$ ), or $\mathrm{BChE}$ (mean $\mathrm{IC}_{50}=19.73 \pm 0.98 \mu \mathrm{M}$ ). This finding suggests that the nature of the $\mathrm{R}^{1}$ substitution drives the level of inhibition probably by increasing/reducing the $\left(\mathrm{R}^{3} \mathrm{O}\right)_{2} \mathrm{P}(\mathrm{O})-\mathrm{X}$ lability; or in other words by favoring the release of the 3-cyanopropyloxy group upon catalytic serinehydroxyl nucleophilic attack.

When a bulky $p$-tolyl group was introduced in $\mathrm{R}^{1}$ position, the corresponding compounds 3c and 3d were found to strongly impair the activity of both enzymes. A clear difference was however observed between both compounds depending on the $\left(\mathrm{R}^{3} \mathrm{O}\right)_{2} \mathrm{P}(\mathrm{O})$ phosphonic ester moiety. In each case, compound 3d in which $\mathrm{R}^{3}=\mathrm{Me}$, exhibited a 1.8- and 2.7-fold lower anticholinesterase activity than $3 \mathbf{c}\left(\mathrm{R}^{3}=\mathrm{Et}\right)$ towards $\mathrm{AChE}$ and $\mathrm{BChE}$, respectively.

This variation in activity could be attributed to the respective hydrophobicity of the $\mathrm{R}^{3}$ chain, i.e. Methyl vs. Ethyl. It is indeed well known that increasing the length of the $n$-alkyl moiety of $\mathrm{R}^{3}$-groups for dialkylphosphates produces an increase in their reactivity with $\mathrm{ChE}$ [23].

Such assumption regarding hydrophobicity effects of our compounds seems, however, necessary but not sufficient to obtain a good inhibition. Replacing the $p-\mathrm{Me}-\mathrm{C}_{6} \mathrm{H}_{4}$ group by the 
less hydrophobic $p$-MeO- $\mathrm{C}_{6} \mathrm{H}_{4}$ group resulted in exactly the reverse reactivity of $\mathbf{3 e} v s$. $3 \mathbf{f}$ towards $\mathrm{AChE}$; while no significant difference in $\mathrm{IC}_{50} \mathrm{~s}$ were observed for the two compounds towards BChE.

Table 3: $\mathrm{IC}_{50}$ values for $\mathrm{AChE}$ and $\mathrm{BChE}$ inhibition.<smiles>[R]C(CN)C([R])OP(=O)=O</smiles>

3

\begin{tabular}{|c|c|c|c|c|c|c|}
\hline $\begin{array}{c}\text { Tested } \\
\text { compound }\end{array}$ & $\mathrm{R}^{1}$ & $\mathrm{R}^{2}$ & $\mathrm{R}^{3}$ & $\mathrm{IC}_{50}$ for $\mathrm{AChE}[\mu \mathrm{M}]^{\mathrm{a}}$ & $\mathrm{IC}_{50}$ for BChE $[\mu \mathrm{M}]^{\mathrm{a}}$ & $\begin{array}{c}\text { Selectivity } \\
\text { to BChE }^{\mathrm{b}}\end{array}$ \\
\hline 3a & $\mathrm{Ph}$ & $\mathrm{H}$ & $\mathrm{Et}$ & $33.64 \pm 0.52$ & $18.13 \pm 0.99$ & 1.85 \\
\hline 3b & $\mathrm{Ph}$ & $\mathrm{H}$ & $\mathrm{Me}$ & $31.39 \pm 1.23$ & $19.25 \pm 0.71$ & 1.63 \\
\hline 3c & $p-\mathrm{Me}-\mathrm{C}_{6} \mathrm{H}_{4}$ & $\mathrm{H}$ & $\mathrm{Et}$ & $\mathbf{9 . 6 1} \pm \mathbf{0 . 9 0}$ & $\mathbf{5 . 9 6} \pm \mathbf{0 . 3 5}$ & 1.61 \\
\hline 3d & $p-\mathrm{Me}-\mathrm{C}_{6} \mathrm{H}_{4}$ & $\mathrm{H}$ & $\mathrm{Me}$ & $\mathbf{1 7 . 2 7} \pm \mathbf{1 . 0 5}$ & $\mathbf{1 6 . 0 1} \pm \mathbf{0 . 4 0}$ & 1.08 \\
\hline 3e & $p-\mathrm{MeO}-\mathrm{C}_{6} \mathrm{H}_{4}$ & $\mathrm{H}$ & $\mathrm{Et}$ & $53.74 \pm 0.51$ & $20.75 \pm 0.91$ & 2.59 \\
\hline 3f & $p-\mathrm{MeO}-\mathrm{C}_{6} \mathrm{H}_{4}$ & $\mathrm{H}$ & $\mathrm{Me}$ & $36.83 \pm 0.64$ & $23.35 \pm 0.89$ & 1.58 \\
\hline 3g & $\mathrm{Ph}$ & $\mathrm{Me}$ & $\mathrm{Et}$ & $35.75 \pm 0.55$ & $17.83 \pm 0.78$ & 2.00 \\
\hline 3h & $\mathrm{Ph}$ & $\mathrm{Me}$ & $\mathrm{Me}$ & $29.48 \pm 0.68$ & $20.57 \pm 0.64$ & 1.43 \\
\hline Rivastigmine & & & $65.24 \pm 0.63$ & $32.47 \pm 0.51$ & 2.01 \\
\hline
\end{tabular}

${ }^{\mathrm{a}} \mathrm{AChE}$ and $\mathrm{BChE}$ inhibition is expressed as the mean $\pm \mathrm{SD}(\mathrm{n}=3$ experiments). The best results for each enzyme are shown in bold.

${ }^{\mathrm{b}}$ Selectivity to $\mathrm{BChE}=\mathrm{IC}_{50}$ for $\mathrm{AChE} / \mathrm{IC}_{50}$ for $\mathrm{BChE}$.

\subsection{In silico molecular docking}

To further investigate the interactions occurring at the enzyme active site during the binding of the dialkyl-3-cyanopropylphosphate derivatives, in silico molecular docking experiments were conducted with compound 3c using the reported crystal structures of AChE (PDB entry code: 5HF5 [24]) and BChE (PDB entry code: 1P0I [25]) as described previously 
[26]. In both cases, the best scoring positions obtained (i.e. lowest energy complex) showed that phosphate moiety adopted a productive orientation (Fig. 1). The reactive phosphorus atom of $\mathbf{3 c}$ was indeed found in a favorable position with the 3-cyano-1-p-tolylpropyloxy group in apical position and opposite to the catalytic serine, thus allowing the occurrence of a nucleophilic attack by this catalytic residue $(\mathrm{d}[\mathrm{Ser}-\mathrm{O} \gamma / \mathrm{P}=\mathrm{O}]$ distance $<2.5 \AA)$ and thus the probable formation of a covalent bond.

The docked 3c-ChE complex was then subjected to interactions analysis using Ligplot+ v.1.4 [27] (Fig. 1C-D) to identify the potential hydrogen bonds and hydrophobic interactions between the ligand (i.e., 3c) and the active site residues of each protein during the binding process. As depicted in Fig. 1C-D, the Ligplot+ analysis shows that the reactive phosphorus atom is stabilized by H-bonding with His447 and Gly116 residues in the case of AChE (Fig. 1C) and BChE (Fig. 1D), respectively. The cyano group may also form hydrogen bond with either Tyr133 (Fig. 1C - AChE), or Leu286 (Fig. 1D - BChE). Moreover, several hydrophobic contacts can be detected that are important to stabilize the inhibitor inside each active site (Fig. 1C-D). Besides all these observations, the main differences between both enzymes resides in their respective active site configuration: a narrow tunnel for $\mathrm{AChE}$, and on the contrary a large open cavity in the case of BChE. Such strong dissimilarities may explain in part the observed selectivity in inhibition towards $\mathrm{BChE}$ vs. AChE. Taken together, all these results therefore might provide a good picture of the inhibition of both enzymes by compound $\mathbf{3 c}$. 

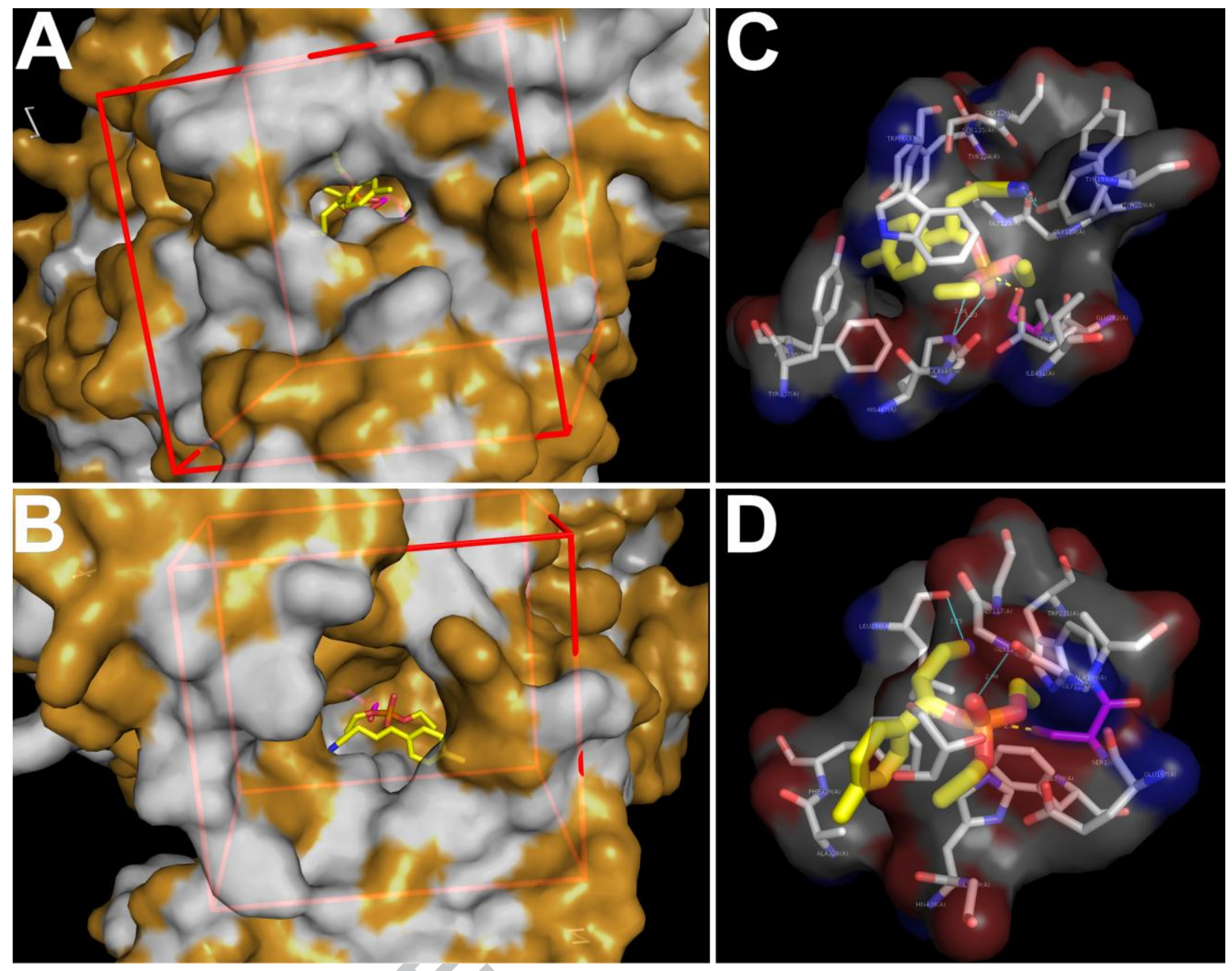

Figure 1. (A-B) In silico molecular docking of 3c into the crystallographic structures of (A) $\mathrm{AChE}$ and $(\mathbf{B}) \mathrm{BChE}$ in a van der Waals surface representation. Hydrophobic residues (alanine, leucine, isoleucine, valine, tryptophan, tyrosine, phenylalanine, proline and methionine) are highlighted in white. (C-D) Ligplot+ analyses results: 3D representation of schematic ligandprotein interactions of $\mathbf{3 c}$ in $(\mathbf{C}) \mathrm{AChE}$ or (D) $\mathrm{BChE}$ active site showing both hydrogen-bonds (cyan lines) and hydrophobic interactions. $3 \mathbf{c}$ is in stick representation with the following atom color-code: oxygen, red; phosphorus, orange; carbon, yellow. The catalytic Serine residues are colored in magenta and are positioned at 2.1 $\AA$ (panel C: Ser203 - AChE) and $2.4 \AA$ (panel D: Ser198 - BChE) from the phosphorus atom of 3c. Structures were drawn with PyMOL Molecular Graphics System (Version 1.4, Schrödinger, LLC) using the PDB files 5HF5 and 1P0I for $\mathrm{AChE}$ and $\mathrm{BChE}$, respectively. 


\section{Conclusions}

An efficient way to prepare previously unreported dialkyl-3-cyanopropylphosphates via the sodium alkoxide-catalysed reaction of dialkyl phosphites with $\gamma$-ketonitriles at $80{ }^{\circ} \mathrm{C}$ under solvent-free conditions has been developed. A possible reaction mechanism, involving a phospha-Brook type rearrangement, has been proposed. This synthetic strategy offers significant advantages such as efficiency, high yields, versatile substituents and mild reaction conditions, making this type of reaction an enhancement for the organic synthesis bibliography. All the title compounds thus synthesized were evaluated against acetylcholinesterase and butyrylcholinesterase showing a significant and higher inhibition of both enzymes than the standard Rivastigmine, with $\mathrm{IC}_{50}$ values in the micromolar range. It was also observed that the activity against butyrylcholinesterase was comparatively higher than that obtained for acetylcholinesterase. Among the synthesized compounds, derivative 3c, which contains the most hydrophobic substituents and displayed the highest inhibitory activity against $\mathrm{AChE}$ and $\mathrm{BChE}$ was further used for in silico molecular docking in both enzymes active site, giving information regarding its binding mode. Anyway, other studies to enrich this first series of promising products and on the modification of the nitrile functionality in 3-compounds to obtain additional dialkyl propylphosphate derivatives with amino or carboxyl units, are ongoing in our laboratory and will be reported in due course. This might further enhance the biological activity of these pharmacophores.

\section{Experimental}

${ }^{1} \mathrm{H},{ }^{31} \mathrm{P}$ and ${ }^{13} \mathrm{C}$ NMR spectra were recorded using $\mathrm{CDCl}_{3}$ as the solvent on a Bruker AC300 spectrometer operating at $300.1 \mathrm{MHz}$ for ${ }^{1} \mathrm{H}, 121.5 \mathrm{MHz}$ for ${ }^{31} \mathrm{P}$ and $75.5 \mathrm{MHz}$ for ${ }^{13} \mathrm{C}$. The chemical shifts are reported in ppm relative to TMS (internal reference) for ${ }^{1} \mathrm{H}$ and ${ }^{13} \mathrm{C}$ NMR and relative to $85 \% \mathrm{H}_{3} \mathrm{PO}_{4}$ (external reference) for ${ }^{31} \mathrm{P}$ NMR. The coupling constants are reported in $\mathrm{Hz}$. The multiplicity of signals is indicated by the following abbreviations: s: singlet; d: doublet; t: triplet; q: quartet; quint: quintet; m: multiplet. Mass spectra were determined on an Agilent 5975B spectrometer under electronic impact (EI) conditions. IR spectra were recorded on a 
Nicolet IR200 spectrometer. The progress of the reactions was monitored by TLC. The purification of the product was performed by column chromatography using silica gel (Fluka).

\subsection{General procedure for the synthesis of dialkyl-3-cyanopropylphosphates 3}

A solution of $0.05 \mathrm{~g}$ of sodium in $1 \mathrm{~mL}$ of dry ethanol (or methanol when using dimethyl phosphite) was added dropwise while stirring at $25{ }^{\circ} \mathrm{C}$ to a mixture of $\gamma$-ketonitrile $(0.01 \mathrm{~mol})$ and dialkylphosphite $(0.05 \mathrm{~mol})$. The reaction mixture was then heated to $80{ }^{\circ} \mathrm{C}$ with constant stirring for $24 \mathrm{~h}$. The excess dialkylphosphite was removed under reduced pressure and then $\mathrm{CHCl}_{3}(50 \mathrm{~mL})$ was added. The organic phase was washed with water $(2 \times 25 \mathrm{~mL})$, dried over $\mathrm{Na}_{2} \mathrm{SO}_{4}$ and concentrated under vacuum. The crude product obtained was chromatographed in a silica gel column using a mixture of ether and hexane (7:3) as an eluent.

Diethyl-3-cyano-1-phenylpropylphosphate (3a): Yellow oil; ${ }^{31} \mathrm{P}$ NMR: $\delta=-3.51 ;{ }^{1} \mathrm{H}$ NMR: $\delta=$ $1.23\left(\mathrm{t}, 3 \mathrm{H},{ }^{3} J_{\mathrm{HH}}=6.0, \mathrm{CH}_{3}-\mathrm{CH}_{2}-\mathrm{O}\right) ; 1.34\left(\mathrm{t}, 3 \mathrm{H},{ }^{3} J_{\mathrm{HH}}=6.0, \mathrm{C}_{3}-\mathrm{CH}_{2}-\mathrm{O}\right) ; 2.14-2.30(\mathrm{~m}, 2 \mathrm{H}$, $\mathrm{CH}_{2}-\underline{\mathrm{C}}_{2}-\mathrm{CN}$ ); 2.37-2.54 (m, 2H, $\mathrm{CH}_{2}-\mathrm{CH}_{2}-\mathrm{CN}$ ); 3.93 (quint, $2 \mathrm{H},{ }^{3} J_{\mathrm{HH}}={ }^{3} J_{\mathrm{PH}}=6.0, \mathrm{CH}_{3}-\underline{\mathrm{CH}}_{2}-$ O); 4.09 (quint, $2 \mathrm{H},{ }^{3} J_{\mathrm{HH}}={ }^{3} J_{\mathrm{PH}}=6.0, \mathrm{CH}_{3}-\underline{\mathrm{CH}}_{2}-\mathrm{O}$ ); 5.34-5.37 (m, 1H, O-C $\underline{\mathrm{H}}-\mathrm{CH}_{2}$ ); 7.35-7.38 $\left(\mathrm{m}, 5 \mathrm{H}\right.$, arom-H); ${ }^{13} \mathrm{C}$ NMR: $\delta=13.2\left(\mathrm{~s}, \mathrm{CH}_{2}-\underline{C H}_{2}-\mathrm{CN}\right) ; 15.7\left(\mathrm{~d},{ }^{3} J_{\mathrm{CP}}=6.0, \underline{\mathrm{CH}}_{3}-\mathrm{CH}_{2}-\mathrm{O}\right) ; 16.1$

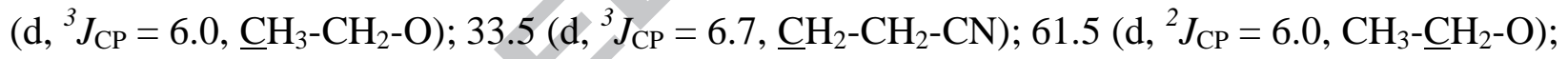
$63.7\left(\mathrm{~d},{ }^{2} J_{\mathrm{CP}}=6.0, \mathrm{CH}_{3}-\mathrm{CH}_{2}-\mathrm{O}\right) ; 78.1\left(\mathrm{~d},{ }^{2} J_{\mathrm{CP}}=6.0, \mathrm{O}-\underline{\mathrm{CH}}-\mathrm{CH}_{2}\right) ; 118.8(\mathrm{~s}, \mathrm{CN})$; phenyl carbons: $\delta=126.02,128.59,128.65,138.62,138.65 ;$ IR (neat): $v_{\mathrm{P}-\mathrm{O}-\mathrm{C}}=1037 \mathrm{~cm}^{-1} ; v_{\mathrm{P}=\mathrm{O}}=1271 \mathrm{~cm}^{-1} ; v_{\mathrm{C} \equiv \mathrm{N}}$ $=2268 \mathrm{~cm}^{-1}$; EI-HRMS: calculated for $\mathrm{C}_{14} \mathrm{H}_{20} \mathrm{NO}_{4} \mathrm{P}: 297.1130\left(\mathrm{M}^{+}\right)$; found: 297.1126 .

Dimethyl-3-cyano-1-phenylpropylphosphate (3b): Yellow oil; ${ }^{31} \mathrm{P}$ NMR: $\delta=0.25 ;{ }^{1} \mathrm{H}$ NMR: $\delta=$ 1.89-2.14 (m, 2H, CH $\left.2-\underline{H}_{2}-\mathrm{CN}\right) ; 2.16-2.34\left(\mathrm{~m}, 2 \mathrm{H}, \mathrm{CH}_{2}-\mathrm{CH}_{2}-\mathrm{CN}\right) ; 3.45$ (d, $3 \mathrm{H},{ }^{3} J_{\mathrm{HP}}=12.0$, $\left.\mathrm{C}_{3}-\mathrm{O}\right) ; 3.53\left(\mathrm{~d}, 3 \mathrm{H},{ }^{3} J_{\mathrm{HP}}=12.0, \mathrm{C}_{3}-\mathrm{O}\right) ; 5.11-5.18\left(\mathrm{~m}, 1 \mathrm{H}, \mathrm{O}-\mathrm{C} \underline{\mathrm{H}}-\mathrm{CH}_{2}\right) ; 7.14-7.17(\mathrm{~m}, 5 \mathrm{H}$, arom-H); ${ }^{13} \mathrm{C}$ NMR: $\delta=13.2\left(\mathrm{~s}, \mathrm{CH}_{2}-\underline{\mathrm{CH}}_{2}-\mathrm{CN}\right) ; 33.2\left(\mathrm{~d},{ }^{3} J_{\mathrm{CP}}=7.5, \underline{\mathrm{CH}}_{2}-\mathrm{CH}_{2}-\mathrm{CN}\right) ; 54.1\left(\mathrm{~d},{ }^{2} J_{\mathrm{CP}}\right.$ $\left.=6.0, \mathrm{CH}_{3}-\mathrm{O}\right) ; 54.2\left(\mathrm{~d},{ }^{2} J_{\mathrm{CP}}=5.3, \mathrm{CH}_{3}-\mathrm{O}\right) ; 78.4\left(\mathrm{~d},{ }^{2} J_{\mathrm{CP}}=5.2, \mathrm{O}-\underline{\mathrm{CH}}-\mathrm{CH}_{2}\right) ; 118.8(\mathrm{~s}, \mathrm{CN})$; phenyl carbons: $\delta=126.01,128.64,128.75,138.38,138.41$; IR (neat): $v_{\mathrm{P}-\mathrm{O}-\mathrm{C}}=1041 \mathrm{~cm}^{-1} ; v_{\mathrm{P}=\mathrm{O}}$ $=1263 \mathrm{~cm}^{-1} ; v_{\mathrm{C} \equiv \mathrm{N}}=2241 \mathrm{~cm}^{-1}$; EI-HRMS: calculated for $\mathrm{C}_{12} \mathrm{H}_{16} \mathrm{NO}_{4} \mathrm{P}: 269.0817\left(\mathrm{M}^{+}\right)$; found: 269.0823. 
Diethyl-3-cyano-1-p-tolylpropylphosphate (3c): Yellow oil; ${ }^{31} \mathrm{P}$ NMR: $\delta=-3.27 ;{ }^{1} \mathrm{H}$ NMR: $\delta=$ $1.13\left(\mathrm{t}, 3 \mathrm{H},{ }^{3} \mathrm{~J}_{\mathrm{HH}}=6.0, \mathrm{CH}_{3}-\mathrm{CH}_{2}-\mathrm{O}\right) ; 1.28\left(\mathrm{t}, 3 \mathrm{H},{ }^{3} J_{\mathrm{HH}}=6.0, \mathrm{CH}_{3}-\mathrm{CH}_{2}-\mathrm{O}\right) ; 2.06-2.23(\mathrm{~m}, 2 \mathrm{H}$, $\mathrm{CH}_{2}-\underline{\mathrm{CH}}_{2}-\mathrm{CN}$ ); 2.26 (s, $\left.\mathrm{CH}_{3}-\mathrm{C}_{6} \mathrm{H}_{4}\right) ; 2.31-2.40\left(\mathrm{~m}, 2 \mathrm{H}, \mathrm{C}_{2}-\mathrm{CH}_{2}-\mathrm{CN}\right.$ ); 3.88 (quint, $2 \mathrm{H},{ }^{3} J_{\mathrm{HH}}=$ ${ }^{3} J_{\mathrm{PH}}=6.0, \mathrm{CH}_{3}-\mathrm{CH}_{2}-\mathrm{O}$ ); 4.14 (quint, $\left.2 \mathrm{H},{ }^{3} J_{\mathrm{HH}}={ }^{3} J_{\mathrm{PH}}=6.0, \mathrm{CH}_{3}-\mathrm{CH}_{2}-\mathrm{O}\right) ; 5.19-5.26(\mathrm{~m}, 1 \mathrm{H}, \mathrm{O}-$ C $\left.\underline{\mathrm{H}}-\mathrm{CH}_{2}\right) ; 7.01-7.24\left(\mathrm{~m}, 4 \mathrm{H}\right.$, arom-H); ${ }^{13} \mathrm{C}$ NMR: $\delta=12.4\left(\mathrm{~s}, \mathrm{CH}_{2}-\mathrm{CH}_{2}-\mathrm{CN}\right) ; 15.2\left(\mathrm{~d},{ }^{3} J_{\mathrm{CP}}=6.7\right.$, $\left.\underline{\mathrm{CH}}_{3}-\mathrm{CH}_{2}-\mathrm{O}\right) ; 15.5\left(\mathrm{~d},{ }^{3} J_{\mathrm{CP}}=5.2, \underline{\mathrm{CH}}_{3}-\mathrm{CH}_{2}-\mathrm{O}\right) ; 19.6\left(\mathrm{~s}, \underline{\mathrm{CH}}_{3}-\mathrm{C}_{6} \mathrm{H}_{4}\right) ; 32.6\left(\mathrm{~d},{ }^{3} J_{\mathrm{CP}}=6.7, \underline{\mathrm{CH}}_{2}-\right.$ $\left.\mathrm{CH}_{2}-\mathrm{CN}\right) ; 60.7\left(\mathrm{~d},{ }^{2} J_{\mathrm{CP}}=5.2, \mathrm{CH}_{3}-\underline{\mathrm{CH}}_{2}-\mathrm{O}\right) ; 61.7\left(\mathrm{~d},{ }^{2} J_{\mathrm{CP}}=6.7, \mathrm{CH}_{3}-\underline{\mathrm{CH}}_{2}-\mathrm{O}\right) ; 77.3\left(\mathrm{~d},{ }^{2} J_{\mathrm{CP}}=5.3\right.$, O- $\left.\underline{\mathrm{CH}}-\mathrm{CH}_{2}\right) ; 117.9$ (s, CN); phenyl carbons: $\delta=125.15,128.59,134.69,134.73,137.69$; IR (neat): $v_{\mathrm{P}-\mathrm{O}-\mathrm{C}}=1052 \mathrm{~cm}^{-1} ; v_{\mathrm{P}=\mathrm{O}}=1267 \mathrm{~cm}^{-1} ; v_{\mathrm{C} \equiv \mathrm{N}}=2271 \mathrm{~cm}^{-1}$; EI-HRMS: calculated for $\mathrm{C}_{15} \mathrm{H}_{22} \mathrm{NO}_{4} \mathrm{P}: 311.1286\left(\mathrm{M}^{+}\right)$; found: 311.1284 .

Dimethyl-3-cyano-1-p-tolylpropylphosphate (3d): Yellow oil; ${ }^{31} \mathrm{P}$ NMR: $\delta=0.17 ;{ }^{1} \mathrm{H}$ NMR: $\delta=$ 1.96-2.13 (m, $\left.2 \mathrm{H}, \mathrm{CH}_{2}-\mathrm{C}_{2}-\mathrm{CN}\right) ; 2.17$ (s, 3H, $\left.\mathrm{CH}_{3}-\mathrm{C}_{6} \mathrm{H}_{4}\right) ; 2.22-2.59$ (m, $2 \mathrm{H}, \mathrm{C}_{2}-\mathrm{CH}_{2}-\mathrm{CN}$ ); $3.58\left(\mathrm{~d}, 3 \mathrm{H},{ }^{3} J_{\mathrm{HP}}=12.0, \mathrm{CH}_{3}-\mathrm{O}\right) ; 3.60\left(\mathrm{~d}, 3 \mathrm{H},{ }^{3} \mathrm{~J}_{\mathrm{HP}}=12.0, \mathrm{CH}_{3}-\mathrm{O}\right) ; 5.13-5.15(\mathrm{~m}, 1 \mathrm{H}, \mathrm{O}-\mathrm{C} \underline{\mathrm{H}}-$ $\left.\mathrm{CH}_{2}\right)$; 6.98-7.29 (m, 4H, arom-H); ${ }^{13} \mathrm{C}$ NMR: $\delta=13.3\left(\mathrm{~s}, \mathrm{CH}_{2}-\mathrm{CH}_{2}-\mathrm{CN}\right) ; 21.4\left(\mathrm{~s}, \mathrm{CH}_{3}-\mathrm{C}_{6} \mathrm{H}_{4}\right)$; $33.0\left(\mathrm{~d},{ }^{2} J_{\mathrm{CP}}=7.5, \underline{\mathrm{CH}}_{2}-\mathrm{CH}_{2}-\mathrm{CN}\right) ; 51.8\left(\mathrm{~d},{ }^{2} J_{\mathrm{CP}}=6.0, \mathrm{CH}_{3}-\mathrm{O}\right) ; 53.6\left(\mathrm{~d},{ }^{2} J_{\mathrm{CP}}=6.7, \mathrm{CH}_{3}-\mathrm{O}\right) ; 78.5$ $\left(\mathrm{d},{ }^{2} J_{\mathrm{CP}}=5.3\right.$, O- $\left.\underline{\mathrm{CH}}-\mathrm{CH}_{2}\right) ; 118.7$ (s, CN); phenyl carbons: $\delta=125.49,128.93,135.29,135.33$, 138.66; IR (neat): $v_{\mathrm{P}-\mathrm{O}-\mathrm{C}}=1054 \mathrm{~cm}^{-1} ; v_{\mathrm{P}=\mathrm{O}}=1263 \mathrm{~cm}^{-1} ; v_{\mathrm{C} \equiv \mathrm{N}}=2263 \mathrm{~cm}^{-1}$; EI-HRMS: calculated for $\mathrm{C}_{13} \mathrm{H}_{18} \mathrm{NO}_{4} \mathrm{P}: 283.0973\left(\mathrm{M}^{+}\right)$; found: 283.0968 .

Diethyl-3-cyano-1-(4-methoxyphenyl)propylphosphate (3e): Yellow oil; ${ }^{31} \mathrm{P}$ NMR: $\delta=-3.59 ;{ }^{1} \mathrm{H}$ NMR: $\delta=1.08$ (t, $\left.3 \mathrm{H},{ }^{3} J_{\mathrm{HH}}=6.0, \mathrm{CH}_{3}-\mathrm{CH}_{2}-\mathrm{O}\right) ; 1.22$ (t, $\left.3 \mathrm{H},{ }^{3} J_{\mathrm{HH}}=6.0, \mathrm{CH}_{3}-\mathrm{CH}_{2}-\mathrm{O}\right) ; 1.75-$ 1.90 (m, 2H, $\left.\mathrm{CH}_{2}-\underline{\mathrm{C}}_{2}-\mathrm{CN}\right) ; 2.19-2.44$ (m, $2 \mathrm{H}, \mathrm{C}_{2}-\mathrm{CH}_{2}-\mathrm{CN}$ ); 3.66 (s, 3H, $\left.\mathrm{C}_{3} \mathrm{O}-\mathrm{C}_{6} \mathrm{H}_{4}\right) ; 4.00$ (quint, $2 \mathrm{H},{ }^{3} J_{\mathrm{HH}}={ }^{3} J_{\mathrm{PH}}=6.0, \mathrm{CH}_{3}-\mathrm{CH}_{2}-\mathrm{O}$ ); 4.12 (quint, $2 \mathrm{H},{ }^{3} J_{\mathrm{HH}}={ }^{3} J_{\mathrm{PH}}=6.0, \mathrm{CH}_{3}-\underline{C}_{2}-\mathrm{O}$ ); 5.71-5.82 (m, $\left.1 \mathrm{H}, \mathrm{O}-\mathrm{C} \underline{\mathrm{H}}-\mathrm{CH}_{2}\right) ; 6.73-7.08\left(\mathrm{~m}, 4 \mathrm{H}\right.$, arom-H); ${ }^{13} \mathrm{C}$ NMR: $\delta=13.6\left(\mathrm{~s}, \mathrm{CH}_{2}-\underline{C}_{2}-\right.$

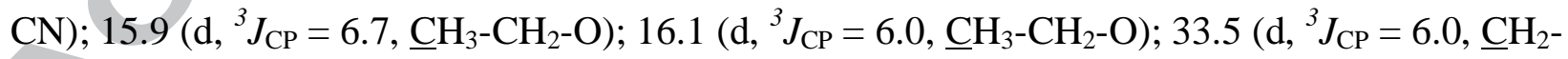

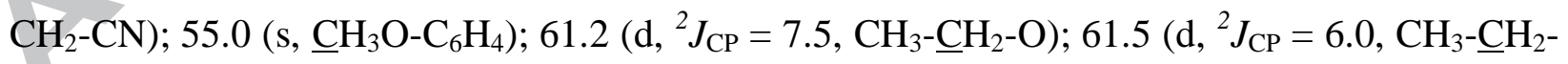
O); 79.0 (s, O-CH-CH ); 119.4 (s, CN); phenyl carbons: $\delta=127.41,128.35,132.92,159.26$; IR (neat): $v_{\mathrm{P}-\mathrm{O}-\mathrm{C}}=1067 \mathrm{~cm}^{-1} ; v_{\mathrm{P}=\mathrm{O}}=1268 \mathrm{~cm}^{-1} ; v_{\mathrm{C}=\mathrm{N}}=2259 \mathrm{~cm}^{-1}$; EI-HRMS: calculated for $\mathrm{C}_{15} \mathrm{H}_{22} \mathrm{NO}_{5} \mathrm{P}: 327.1236\left(\mathrm{M}^{+}\right)$; found: 327.1239 . 
Dimethyl-3-cyano-1-(4-methoxyphenyl)propylphosphate (3f): Yellow oil; ${ }^{31} \mathrm{P}$ NMR: $\delta=0.77 ;{ }^{1} \mathrm{H}$ NMR: $\delta=1.71-1.88\left(\mathrm{~m}, 2 \mathrm{H}, \mathrm{CH}_{2}-\underline{\mathrm{C}}_{2}-\mathrm{CN}\right) ; 2.25-2.36\left(\mathrm{~m}, 2 \mathrm{H}, \mathrm{C}_{2}-\mathrm{CH}_{2}-\mathrm{CN}\right) ; 3.52(\mathrm{~s}, 3 \mathrm{H}$, $\left.\mathrm{CH}_{3} \mathrm{O}-\mathrm{C}_{6} \mathrm{H}_{4}\right) ; 3.55\left(\mathrm{~d}, 3 \mathrm{H},{ }^{3} J_{\mathrm{HP}}=12.0, \mathrm{CH}_{3}-\mathrm{O}-\mathrm{P}\right) ; 3.58\left(\mathrm{~d}, 3 \mathrm{H},{ }^{3} J_{\mathrm{HP}}=12.0, \mathrm{CH}_{3}-\mathrm{O}-\mathrm{P}\right) ; 5.49-5.54$

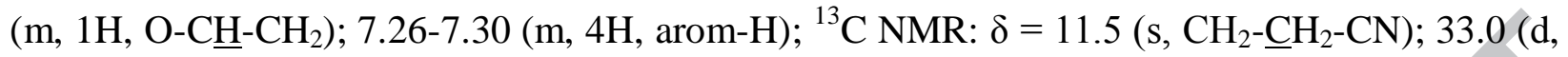
$\left.{ }^{3} J_{\mathrm{CP}}=8.2, \underline{\mathrm{CH}}_{2}-\mathrm{CH}_{2}-\mathrm{CN}\right) ; 51.7\left(\mathrm{~s}, \mathrm{CH}_{3} \mathrm{O}-\mathrm{C}_{6} \mathrm{H}_{4}\right) ; 53.7\left(\mathrm{~d},{ }^{2} J_{\mathrm{CP}}=7.5, \mathrm{CH}_{3}-\mathrm{O}-\mathrm{P}\right) ; 53.8\left(\mathrm{~d},{ }^{2} J_{\mathrm{CP}}=\right.$ 7.5, $\mathrm{CH}_{3}-\mathrm{O}-\mathrm{P}$ ); 77.6 (s, O- $\underline{\mathrm{CH}}-\mathrm{CH}_{2}$ ); 119.7 (s, CN); phenyl carbons: $\delta=127.28,129.16,130.11$, 159.07; IR (neat): $v_{\mathrm{P}-\mathrm{O}-\mathrm{C}}=1062 \mathrm{~cm}^{-1} ; v_{\mathrm{P}=\mathrm{O}}=1273 \mathrm{~cm}^{-1} ; v_{\mathrm{C} \equiv \mathrm{N}}=2258 \mathrm{~cm}^{-1}$; EI-HRMS: calculated for $\mathrm{C}_{13} \mathrm{H}_{18} \mathrm{NO}_{5} \mathrm{P}: 299.0923\left(\mathrm{M}^{+}\right)$; found: 299.0916.

Diethyl-3-cyano-2-methyl-1-phenylpropylphosphate (3g): Yellow oil; ${ }^{31} \mathrm{P}$ NMR: $\delta=-3.3(\mathrm{~min})$, 2.4 (maj); \% maj/min: 58/42; ${ }^{1} \mathrm{H}$ NMR: $\delta=1.12-1.28$ (m, 9H, $2 \mathrm{C}_{3}-\mathrm{CH}_{2}-\mathrm{O}$ and $\mathrm{C}_{3}-\mathrm{CH}$ ); $2.40-$ 2.54 (m, $\left.\mathrm{CH}-\mathrm{CH}_{2}-\mathrm{CN}\right) ; 2.56-2.72$ (m, $\left.1 \mathrm{H}, \mathrm{CH}-\mathrm{CH}_{2}-\mathrm{CN}\right) ; 3.86-4.12$ (m, 4H, $\mathrm{CH}_{3}-\mathrm{CH}_{2}-\mathrm{O}$ ); $5.72-$ $5.78(\mathrm{~m}, 1 \mathrm{H}, \mathrm{O}-\mathrm{C} \underline{\mathrm{H}}-\mathrm{CH}) ; 7.22-7.58(\mathrm{~m}, 5 \mathrm{H}$, arom-H$) ;{ }^{13} \mathrm{C} \mathrm{NMR}: \delta=15.9\left(\mathrm{~d},{ }^{3} J_{\mathrm{CP}}=6.0, \underline{\mathrm{CH}_{3}-}\right.$ $\left.\mathrm{CH}_{2}-\mathrm{O}\right) ; 16.2\left(\mathrm{~d},{ }^{3} J_{\mathrm{CP}}=6.0, \underline{\mathrm{CH}}_{3}-\mathrm{CH}_{2}-\mathrm{O}\right) ; 17.8$ (s, $\left.\mathrm{CH}_{-} \mathrm{CH}_{2}-\mathrm{CN}\right) ; 18.3$ (s, $\left.\underline{\mathrm{CH}}_{3}-\mathrm{CH}, \min \right) ; 20.0$ (s, $\left.\mathrm{CH}_{3}-\mathrm{CH}, \mathrm{maj}\right) ; 37.8\left(\mathrm{~d},{ }^{3} J_{\mathrm{CP}}=6.0, \underline{\mathrm{CH}}-\mathrm{CH}_{2}-\mathrm{CN}\right) ; 61.5\left(\mathrm{~d},{ }^{2} J_{\mathrm{CP}}=5.2, \mathrm{CH}_{3}-\underline{\mathrm{CH}}_{2}-\mathrm{O}\right) ; 63.4\left(\mathrm{~d},{ }^{2} J_{\mathrm{CP}}\right.$ $\left.=6.0, \mathrm{CH}_{3}-\underline{\mathrm{CH}_{2}-\mathrm{O}}\right) ; 80.2\left(\mathrm{~d},{ }^{2} J_{\mathrm{CP}}=6.0, \mathrm{O}-\underline{\mathrm{CH}}-\mathrm{CH}\right) ; 118.4$ (s, CN, maj); 118.5 (s, CN, min); phenyl carbons: $\delta=126.93,127.74,128.29,128.37,128.75,129.16,134.58,134.61,137.50$, 137.53; IR (neat): $v_{\mathrm{P}-\mathrm{O}-\mathrm{C}}=1088 \mathrm{~cm} 1 ; v_{\mathrm{P}=\mathrm{O}}=1268 \mathrm{~cm}^{-1} ; v_{\mathrm{C}=\mathrm{N}}=2241 \mathrm{~cm}^{-1}$; EI-HRMS: calculated for $\mathrm{C}_{15} \mathrm{H}_{22} \mathrm{NO}_{4} \mathrm{P}: 311.1286\left(\mathrm{M}^{+}\right)$; found: 311.1281 .

Dimethyl-3-cyano-2-methyl-1-phenylpropylphosphate (3h): Yellow oil; ${ }^{31} \mathrm{P}$ NMR: $\delta=0.20$ (min), 0.37 (maj); \% maj/min: 63/37; ${ }^{1} \mathrm{H}$ NMR: $\delta=1.05$ (d, $3 \mathrm{H},{ }^{3} J_{\mathrm{HH}}=6.0, \mathrm{CH}_{3}-\mathrm{CH}, \mathrm{min}$ ); 1.12 $\left(\mathrm{d}, 3 \mathrm{H},{ }^{3} J_{\mathrm{HH}}=6.0, \mathrm{CH}_{3}-\mathrm{CH}, \mathrm{maj}\right) ; 1.90-2.14\left(\mathrm{~m}, 2 \mathrm{H}, \mathrm{CH}-\underline{\mathrm{CH}}_{2}-\mathrm{CN}\right) ; 2.21-2.60\left(\mathrm{~m}, 1 \mathrm{H}, \mathrm{C} \underline{\mathrm{H}}-\mathrm{CH}_{2}-\right.$ $\mathrm{CN}) ; 3.62\left(\mathrm{~d}, 3 \mathrm{H},{ }^{3} J_{\mathrm{HP}}=12.0, \underline{\mathrm{CH}}_{3}-\mathrm{O}\right) ; 3.68\left(\mathrm{~d}, 3 \mathrm{H},{ }^{3} J_{\mathrm{HP}}=12.0, \mathrm{C}_{3}-\mathrm{O}\right) ; 5.12-5.18(\mathrm{~m}, 1 \mathrm{H}, \mathrm{O}-$ C $\underline{H}-\mathrm{CH}) ; 7.12-7.64\left(\mathrm{~m}, 5 \mathrm{H}\right.$, arom-H); ${ }^{13} \mathrm{C}$ NMR: $\delta=15.7$ (s, $\left.\mathrm{CH}-\underline{C H}_{2}-\mathrm{CN}\right) ; 18.5$ (s, $\underline{\mathrm{CH}}_{3}-\mathrm{CH}$, maj); 20.6 (s, $\left.\underline{\mathrm{CH}}_{3}-\mathrm{CH}, \mathrm{min}\right) ; 37.5$ (d, $\left.{ }^{3} J_{\mathrm{CP}}=6.7, \underline{\mathrm{CH}}-\mathrm{CH}_{2}-\mathrm{CN}\right) ; 51.9$ (d, $\left.{ }^{2} J_{\mathrm{CP}}=6.0, \mathrm{CH}_{3}-\mathrm{O}\right)$; $52.1\left(\mathrm{~d},{ }^{2} J_{\mathrm{CP}}=6.0, \mathrm{CH}_{3}-\mathrm{O}\right) ; 81.0\left(\mathrm{~d},{ }^{2} J_{\mathrm{CP}}=6.0, \mathrm{O}-\underline{\mathrm{CH}}-\mathrm{CH}\right) ; 118.2(\mathrm{~s}, \mathrm{CN}, \mathrm{maj}) ; 118.6$ (s, CN, min); phenyl carbons: $\delta=126.41,126.79,128.08,128.26,128.70,129.29,137.32,137.35$, 137.60, 137.72; IR (neat): $v_{\mathrm{P}-\mathrm{O}-\mathrm{C}}=1066 \mathrm{~cm}^{-1} 1 ; v_{\mathrm{P}=\mathrm{O}}=1274 \mathrm{~cm}^{-1} ; v_{\mathrm{C}=\mathrm{N}}=2271 \mathrm{~cm}^{-1}$; EI-HRMS: calculated for $\mathrm{C}_{13} \mathrm{H}_{18} \mathrm{NO}_{4} \mathrm{P}: 283.0973\left(\mathrm{M}^{+}\right)$; found: 283.0965 . 


\subsection{Determination of $I C_{50}$ for cholinesterases}

The $\mathrm{IC}_{50}$ values were determined using the spectrophotometric Ellman's method [20], widely used for evaluating cholinesterase activity and screening potential inhibitors. Cholinesterase activity is measured indirectly by quantifying the concentration of the 5-thio-2nitrobenzoic acid (TNB) ion formed in the reaction between the thiol reagent 5,5'-dithiobis-2nitrobenzoic acid (DTNB) and thiocholine, a product of substrate hydrolysis (i.e., acetylthiocholine, ATCh) by cholinesterases [28]. The eight synthesized dialkyl-3cyanopropylphosphates (3a-h) were dissolved in $0.01 \mathrm{M}$ dimethyl sulphoxide and then diluted in demineralized water to $1 \mathrm{mM}$ and $0.1 \mathrm{mM}$. Pursuing the procedure described in [21], the activities were determined as follows: the reaction mixture containing the phosphate buffer, $\mathrm{AChE}$ or $\mathrm{BChE}$ and the chosen dialkyl-3-cyanopropylphosphate, was prepared and intensively stirred. DTNB and ATCh were then added to the sample and mixed, and the absorbance was then measured at $405 \mathrm{~nm}$ using a Thermo Scientific Multiskan FC Microplate Photometer.

Electric eel AChE (Type-VI-S, EC 3.1.1.7; Sigma, St. Louis, USA) and horse serum BChE (EC 3.1.1.8; Sigma) were used.

Rivastigmine (Sigma) was used as reference drug.

\subsection{Molecular docking experiments}

In silico molecular docking of compound $\mathbf{3 c}$ present in the active site of $\mathrm{AChE}$ and $\mathrm{BChE}$ was performed with the Autodock Vina program [29] as previously described [26]. The PyMOL Molecular Graphics System (version 1.4, Schrödinger, LLC) was used as working environment with an in-house version of the AutoDock/Vina PyMOL plugin [30]. The X-ray crystallographic structures of AChE (PDB entry code: 5HF5; $2.15 \AA$ A resolution [24]), and BChE (PDB entry code: 1P0I; $2.00 \AA$ A resolution [25]) available at the Protein Data Bank were used as receptors. Docking runs were performed after replacing the catalytic serine by a glycine residue to enable the ligand to adopt a suitable position corresponding to the pre-bound intermediate before the nucleophilic attack in the enzyme active site. The box size used for the various receptors was chosen to fit the whole active site cleft and to allow non constructive binding positions. A model structure file was generated for the inhibitor molecule, and its geometry was refined using the Avogadro open-source program (version 1.1.1. http://avogadro.openmolecules.net/). 


\section{Conflict of interest}

The authors declare no conflict of interest.

\section{Acknowledgements}

The authors are grateful to the Tunisian Ministry of Higher Education and Scientific Research for its financial support.

\section{References}

[1] P.T. Francis, A.M. Palmer, M. Snape, G.K. Wilcock, The cholinergic hypothesis of Alzheimer's disease: A review of progress, J. Neurol. Neurosurg. Psychiatry. 66 (1999) 137147.

[2] D. Kidd, Y. Liu, B.F. Cravatt, Profiling serine hydrolase activities in complex proteomes, Biochemistry. 40 (2001) 4005-4015.

[3] S. Schwarz, S.D. Lucas, S. Sommerwerk, R. Csuk, Amino derivatives of glycyrrhetinic acid as potential inhibitors of cholinesterases, Bioorg. Med. Chem. 22 (2014) 3370-3378.

[4] A. Saeed, P.A. Mahesar, S. Zaib, M.S. Khan, A. Matin, M. Shahid, J. Iqbal, Synthesis, cytotoxicity and molecular modelling studies of new phenylcinnamide derivatives as potent inhibitors of cholinesterases, Eur. J. Med. Chem. 22 (2014) 43-53.

[5] S. Darvesh, D.A. Hopkins, C. Geula, Neurobiology of butyrylcholinesterase, Nat. Rev. Neurosci. 4 (2003) 131-138.

[6] B. Li, J.A. Stribley, A. Ticu, W. Xie, L.M. Schopfer, P. Hammond, S. Brimijoin, S.H. Hinrichs, O. Lockridge, Abundant tissue butyrylcholinesterase and its possible function in the acetylcholinesterase knockout mouse, J. Neurochem. 75 (2000) 1320-1331.

[7] G.A. Reid, N. Chilukuri, S. Darvesh, Butyrylcholinesterase and the cholinergic system, Neurosci. 234 (2013) 53-68. 
[8] M. Pohanka, Cholinesterases, a target of pharmacology and toxicology, Biomed. Pap. Med. 155 (2011) 219-229.

[9] R. Heinig, D. Zimmer, S. Yeh, G.J. Krol, Development, validation and application of assays to quantify metrifonate and 2,2-dichlorovinyl dimethylphosphate in human body fluids, $\mathrm{J}$. Chromatogr. B. 741 (2000) 257-269.

[10]B. Ibach, E. Haen, Acetylcholinesterase inhibition in Alzheimer's Disease, Curr. Pharm. Des.10 (2004) 231-251.

[11] M. Kratky, S. Stepankova, K. Vorcakova, J. Vinsova, Salicylanilide diethyl phosphates as cholinesterases inhibitors, Bioorg. Chem. 58 (2015) 48-52.

[12] J. Bajgar, Organophosphates/nerve agent poisoning: mechanism of action, diagnosis, prophylaxis, and treatment, Adv. Clin. Chem. 38 (2004) 151-216.

[13] (a) M.C. Franklin, M.J. Rudolph, C. Ginter, M.S. Cassidy, J. Cheung, Structures of paraoxon-inhibited human acetylcholinesterase reveal perturbations of the acyl loop and the dimer interface, Proteins, 84 (2016) 1246-1256. (b) K. Nakayama, J.P. Schwans, E.J. Sorin, T. Tran, J. Gonzalez, E. Arteaga, S. McCoy, W. Alvarado, Synthesis, biochemical evaluation, and molecular modeling studies of aryl and arylalkyl di-n-butyl phosphates, effective butyrylcholinesterase inhibitors, Bioorg. Med. Chem. (2017), doi.org/10.1016/j.bmc.2017.04.002.

[14]P. Taylor, Z. Radic, N.A. Hosca, S. Camp, P. Marchot, H.A. Berman, Structural bases for the specificity of cholinesterase catalysis and inhibition, Toxicol. Lett. 82-83 (1995) 453458.

[15] M.B. Colovic, D.Z. Krstic, T.D. Lazarevic-Pasti, A.M. Bondzic, V.M. Vasic, Acetylcholinesterase Inhibitors: Pharmacology and Toxicology, Curr. Neuropharmacol. 11 (2013) 315-335.

[16] J. Vinsova, M. Kratky, M. Komloova, E. Dadapeer, S. Stepankova, K. Vorcakova, J. Stolarikova, Diethyl 2-(phenylcarbamoyl)phenyl phosphorothioates: synthesis, antimycobacterial activity and cholinesterase inhibition, Molecules 19 (2014) 7152-7168. 
[17]F.F. Fleming, L. Yao, P.C. Ravikumar, L. Funk, B.C. Shook, Nitrile-containing pharmaceuticals: efficacious roles of the nitrile pharmacophore, J. Med. Chem. 53 (2010) 7902-7917.

[18]I. Aouani, K. Lahbib, S. Touil, Green synthesis and antioxidant activity of novel $\gamma$-cyano- $\alpha-$ hydroxyphosphonate derivatives, Med. Chem. 11 (2015) 206-213.

[19] (a) L. El Kaïm, L. Gaultier, L. Grimaud, A. Dos Santos, Formation of new phosphates from aldehydes by a DBU-catalysed Phospha-Brook rearrangement in a polar solvent, Synlett. (2005) 2335-2336; (b) A.S. Demir, B. Reis, O. Reis, S. Eymur, M. Gollu, S. Tural, G. Saglam, Cyanide Ion Promoted Addition of Acyl Phosphonates to Ethyl Cyanoformate: $\gamma$ Synthesis of Tertiary Carbinols via Tandem Carbon-Carbon Bond Formations, J. Org. Chem. 72 (2007) 7439-7442; (c) A.S. Demir, I. Esiringu, M. Gollu, O. Reis, Catalytic Intermolecular Aldehyde-Ketone Coupling via Acyl Phosphonates, J. Org. Chem. 74 (2009) 2197-2199; (d) M. Hayashi, S. Nakamura, Catalytic Enantioselective Protonation of $\alpha$ Oxygenated Ester Enolates Prepared through Phospha-Brook Rearrangement, Angew. Chem., Int. Ed. 50 (2011) 2249-2252; (e) A. Kondoh, M. Terada, Brønsted base catalyzed [2,3]-Wittig/phospha-Brook tandem rearrangement sequence, Org. Lett. 15 (2013) 45684571; (f) A. Kondoh, T. Aoki, M. Terada, Intramolecular cyclization of alkynyl $\alpha-$ ketoanilide utilizing [1,2]-phospha-Brook rearrangement catalyzed by phosphazene base, Org. Lett. 16 (2014) 3528-3531; (g) A. Kondoh, M. Terada, Brønsted base-catalyzed $\alpha-$ oxygenation of carbonyl compounds utilizing the [1,2]-phospha-Brook rearrangement, Org. Chem. Front. 2 (2015) 801-805.

[20] G.L. Ellman, K.D. Courtney, V.Jr. Andres, R.M. Featherstone, A new and rapid colorimetric determination of acetylcholinesterase activity, Biochem. Pharmacol. 7 (1961) 88-95.

[21]E. Carletti, N. Aubrek, E. Gillon, M. Loiodice, Y. Nicolet, J.C. Fontecilla-Camps, P. Masson, H. Thiermann, F. Nachon, F. Worek, Structure-activity analysis of aging and reactivation of human butyrylcholinesterase inhibited by analogues of tabun, Biochem. J. 421 (2009) 97-106. 
[22]B. Kaboudin, S. Emadi, A. Hadizadeh, Synthesis of novel phosphorothioates and phosphorodithioates and their differential inhibition of cholinesterases, Bioorg. Chem. 37 (2009) 101-105.

[23]D.M. Maxwell and D.E. Lenz, Structure-activity relationships and anticholinesterase activity, In Clinical and Experimental Toxicology of Organophosphates and Carbamates, (Ballantyne B. and Marrs T. C., Eds.) Butterworth-Heinemann, Oxford, 1992, pp 47-58.

[24] M.C. Franklin, M.J. Rudolph, C. Ginter, M.S. Cassidy, J. Cheung, Structures of paraoxoninhibited human acetylcholinesterase reveal perturbations of the acyl loop and the dimer interface, Proteins 84 (2016) 1246-1256.

[25] Y. Nicolet, O. Lockridge, P. Masson, J.C. Fontecilla-Camps, F. Nachon, Crystal Structure of Human Butyrylcholinesterase and of Its Complexes with Substrate and Products, J. Biol. Chem. 278 (2003) 41141-41147.

[26] (a) V. Point, R.K. Malla, S. Diomande, B.P. Martin, V. Delorme, F. Carriere, S. Canaan, N.P. Rath, C.D. Spilling, J.-F. Cavalier, Synthesis and kinetic evaluation of Cyclophostin and Cyclipostins phosphonate analogs as selective and potent inhibitors of microbial lipases. J. Med. Chem. 55 (2012) 10204-10219. (b) V. Point, A. Bénarouche, J. Zarillo, A. Guy, R. Magnez, L. Fonseca, B. Raux, J. Leclaire, G. Buono, F. Fotiadu, T. Durand, F. Carrière, C. Vaysse, L. Couëdelo, J.-F. Cavalier, Slowing down fat digestion and absorption by an oxadiazolone inhibitor targeting selectively gastric lipolysis. Eur. J. Med. Chem. 123 (2016) 834-848.

[27] R.A. Laskowski, M.B. Swindells, LigPlotp: multiple ligand protein interaction diagrams for drug discovery, J. Chem. Inf. Model. 51 (2011) 2778-2786.

[28] G. Sinko, M. Calic, A. Bosak, Z. Kovarik, Limitation of the Ellman method: cholinesterase activity measurement in the presence of oximes, Anal. Biochem. 370 (2007) 223-227.

[29] O. Trott, A.J. Olson, AutoDock Vina: improving the speed and accuracy of docking with a new scoring function, efficient optimization, and multithreading, J. Comput. Chem. 31 (2010) 455-461. 
[30]D. Seeliger, B.L. de Groot, Ligand docking and binding site analysis with PyMOL and Autodock/Vina, J. Comput. Aided Mol. Des. 24 (2010) 417-422. 
Graphical abstract

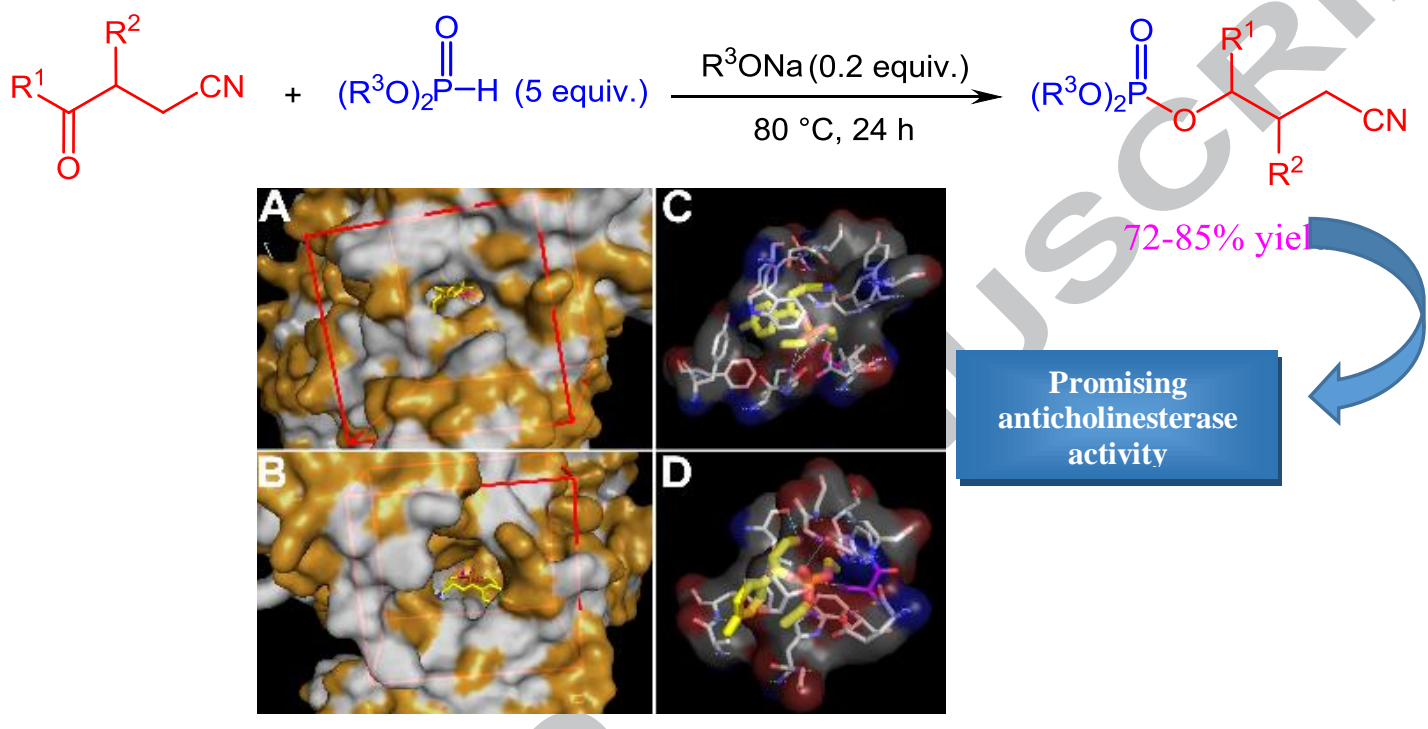




\section{Highlights}

- First synthesis of dialkyl-3-cyanopropylphosphate derivatives.

- Possible reaction mechanism, involving a phospha-Brook type rearrangement.

- In vitro studies of the synthesized compounds as possible inhibitors of acetylcholinesterase and butyrylcholinesterase.

- They showed higher inhibition of both enzymes than the standard Rivastigmine.

- They behave more selectively towards butyrylcholinesterase.

- In silico molecular docking in both enzymes active site, gave information regarding the binding mode. 